\title{
Clinician and patient experience of neurology telephone consultations during the COVID-19 pandemic.
}

\author{
Tagore Nakornchai ${ }^{1,2}$, Elena Conci $^{2}$, Anke Hensiek ${ }^{2}$, J William L Brown ${ }^{1-3}$ \\ 1: Department of Clinical Neurosciences, University of Cambridge, Cambridge, United Kingdom \\ 2: Department of Neurology, Addenbrookes' Hospital, Cambridge University Hospitals NHS Foundation Trust, \\ Cambridge, United Kingdom \\ 3: Clinical Outcomes Research Unit (CORe), University of Melbourne, Melbourne, Australia \\ Corresponding Author: tagore.nakornchai@,nhs.net
}

\begin{abstract}
(max 250 words)
Background: Telephone consultations are already employed in specific neurological settings. At Cambridge University Hospitals, the COVID-19 pandemic initially prompted almost all face-to-face appointments to be delivered by telephone, providing a uniquely unselected population to assess.
\end{abstract}

Objectives: We explored patient and clinician experience of telephone consultations; and whether telephone consultations might be preferable for pre-identifiable subgroups of patients after the pandemic.

Methods: Clinicians delivering neurological consultations converted to telephone between April-July 2020 were invited to complete a questionnaire following each consult (430 respondents) and the corresponding patients were subsequently surveyed (290 respondents). The questionnaires assessed clinician and patient goal achievement (and the reasons for any dissatisfaction). Clinicians also described consultation duration (in comparison to faceto-face) while patients detailed comparative convenience and preference.

Results: The majority of clinicians $(335 / 430,78 \%)$ and patients $(227 / 290,78 \%)$ achieved their consultation goals by telephone, particularly during follow-up consultations (clinicians 272/329, 83\%, patients 176/216,81\%) and in some disease subgroups (e.g. seizures/epilepsy (clinicians 114/122 (93\%), patients 71/81 (88\%)). 95\% of telephone consultations were estimated to take the same or less time than an equivalent face-to-face consultation. Most patients found telephone consultations convenient (69\%) with 149/211 (71\%) indicating they would like telephone or video consultations to play some role in their future follow-up.

Conclusion: Telephone consultations appear effective, convenient and popular in prespecified subgroups of neurological outpatients. Further work comparing telephone, video and face-to-face consultations across multiple centres is now needed.

\section{Keywords (4-6 keywords for indexing purposes)}

COVID-19; Neurology; Outpatient; Communication; Telemedicine; Telephone.

NOTE: This preprint reports new research that has not been certified by peer review and should not be used to guide clinical practice. 
medRxiv preprint doi: https://doi.org/10.1101/2021.09.26.21264141; this version posted September 27,2021 . The copyright holder for this preprint (which was not certified by peer review) is the author/funder, who has granted medRxiv a license to display the preprint in

It is made available under a CC-BY-NC-ND 4.0 International license .

\section{Introduction}

The COVID-19 pandemic caused significant disruption to hospital outpatient appointments. As community infection rates increased, most centres cancelled all but the most urgent face-to-face appointments to minimise COVID-19 transmission to and from patients.

Prior to the pandemic, telemedicine was already employed in specific neurologic settings, including where geographic barriers preclude assessment of remote populations [1,2], in time sensitive settings such as acute stroke $[3,4]$ or where patient access to care may be impeded by disease-related driving restrictions such as epilepsy $[5,6]$. A pre-pandemic review of telemedicine by the American Academy of Neurology indicated its benefits in terms of cost, access and noninferiority, but highlighted the need to validate its use in a variety of populations and settings.[7]

Telemedicine mitigates infection concerns and is sometimes more convenient for patients (particularly those of working-age or those whose diagnosis requires driving restrictions). However, face to face clinical examinations ( for example testing of reflexes) are not possible and previous models for general neurological telemedicine often relied on movable cameras and clinical assistants to be present with the patient[2].

During the COVID-19 pandemic many centres switched face-to-face appointments to telephone consultations, presenting a unique opportunity to assess patient and clinician experience of this medium. From late March 2020, in line with recommendations from NHS England[8], virtually all neurology clinic appointments at Cambridge University Hospitals were converted to telephone consultations, providing an unselected non-biased group of care episodes to explore. This tertiary centre provides general and specialist neurology services across a large urban and rural catchment area including multiple relatively sparsely populated counties in the East Anglian region of England.

We aimed to explore the benefits and limitations of outpatient telephone consultations in neurology from both the clinician and patient perspective; to identify whether telephone consultations are preferable to face-to-face consultations in particular settings after the pandemic, trying to identify demographic and clinical factors that are associated with successful consultations, and identify the deficiencies in the format compared to face-to-face consultations..

\section{Methods}

Between the $22^{\text {nd }}$ of April and $3^{\text {rd }}$ of July 2020, all consultants and specialist nurses delivering telephone outpatient neurology consultations as a substitute for face-to-face appointments at Cambridge University Hospitals were invited to complete an eight-question Clinician Questionnaire immediately after each consultation where the patient answered the telephone (Appendix A). This asked whether clinicians accomplished their goals for the consultation; and if not, what was not accomplished, whether this was due to the telephone consultation and whether a video consultation would have achieved their objectives. Finally, clinicians were asked about if the telephone appointment was longer or shorter than a face-to-face appointment. 
medRxiv preprint doi: https://doi.org/10.1101/2021.09.26.21264141; this version posted September $27,2021$. The copyright holder for this preprint (which was not certified by peer review) is the author/funder, who has granted medRxiv a license to display the preprint in

It is made available under a CC-BY-NC-ND 4.0 International license.

All patients participating in neurology telephone clinics during the same time period were sent a postal Patient Questionnaire exploring their experience (Appendix B). This explored whether patients felt they achieved their aims during the consultation (and if so, what), whether it affected the doctor-patient relationship as well as more practical questions about time taken to attend in-person appointments and where relevant, time off work to attend face-to-face appointments. Finally, patients were asked whether they found telephone or face-to-face clinics more practical before seeking their preferences for telephone, video or face-to-face appointments future appointments in the future. The last question was modified to include combination options due to patient feedback. Where Clinician Questionnaires had no corresponding Patient Questionnaire, the patient was called by telephone to explore their experience ( 2 attempts, at different times of day, on different days); and where a Clinician Questionnaire was missing despite a returned Patient Questionnaire, the clinician was contacted to explore their experience. An interim review revealed several subspecialties were under-represented; for those subspecialties where telephone consultations were still being offered to all patients, telephone consultations between July 3rd and September 8th were also surveyed.

The patient's healthcare records were then reviewed for key demographics, presenting complaint, diagnoses and concomitant psychiatric diagnoses. The patient's level of neurological disability and socioeconomic grade were estimated using the Modified Rankin Score[9][10] and the NRS Social Grade classification respectively.

\section{Results}

\section{Questionnaire Demographics}

Four hundred and thirty clinician questionnaires were received from 18 clinicians (2 Clinical Nurse Specialists, 16 Consultant Neurologists), all describing consultations with different patients. Within these, 290 consultations (67\%) had a corresponding patient questionnaire ( 80 postal questionnaires, 210 by telephone); the demographics of responders were not significantly different to non-responders (Table S1, Supplementary Data). A quarter of consultations were for new patients (Table 1). The presenting complaint (for new consultations, $\mathrm{n}=101$ ) and the primary diagnosis (for follow-up consultations, $\mathrm{n}=329$ ) are listed in Tables 3.

Table 1: Overall Patient Demographics

\begin{tabular}{|l|l|l|l|}
\hline Patient Demographics & \multicolumn{2}{|l|}{ Type of Consultation } \\
\cline { 2 - 4 } & New & Follow-up & All \\
\hline Number & 101 & 329 & 430 \\
\hline Mean Age (SD, Range) & $52.7(20.7,17-93)$ & $54.9(18.2,17-90)$ & $54.3(18.8,17-93)$ \\
\hline Gender (Male/Female) & $42 / 59$ & $145 / 184$ & $187 / 243$ \\
\hline
\end{tabular}

Table 1. SD: Standard Deviation

\section{Clinician Questionnaires}

Clinicians were able to achieve their goals in 335/430 (78\%) of telephone consultations. Clinician goals were achieved more often than not across all demographic subgroups (Table 2). Clinicians achieved their goals most 
medRxiv preprint doi: https://doi.org/10.1101/2021.09.26.21264141; this version posted September 27, 2021. The copyright holder for this preprint (which was not certified by peer review) is the author/funder, who has granted medRxiv a license to display the preprint in It is made available under a CC-BY-NC-ND 4.0 International license.

frequently with younger patients and in follow-up appointments $(272 / 329,83 \%)$ compared to new consultations $(63 / 101,62 \%)$.

Table 2: Telephone consultations: goal achievement from clinician and patient questionnaires.

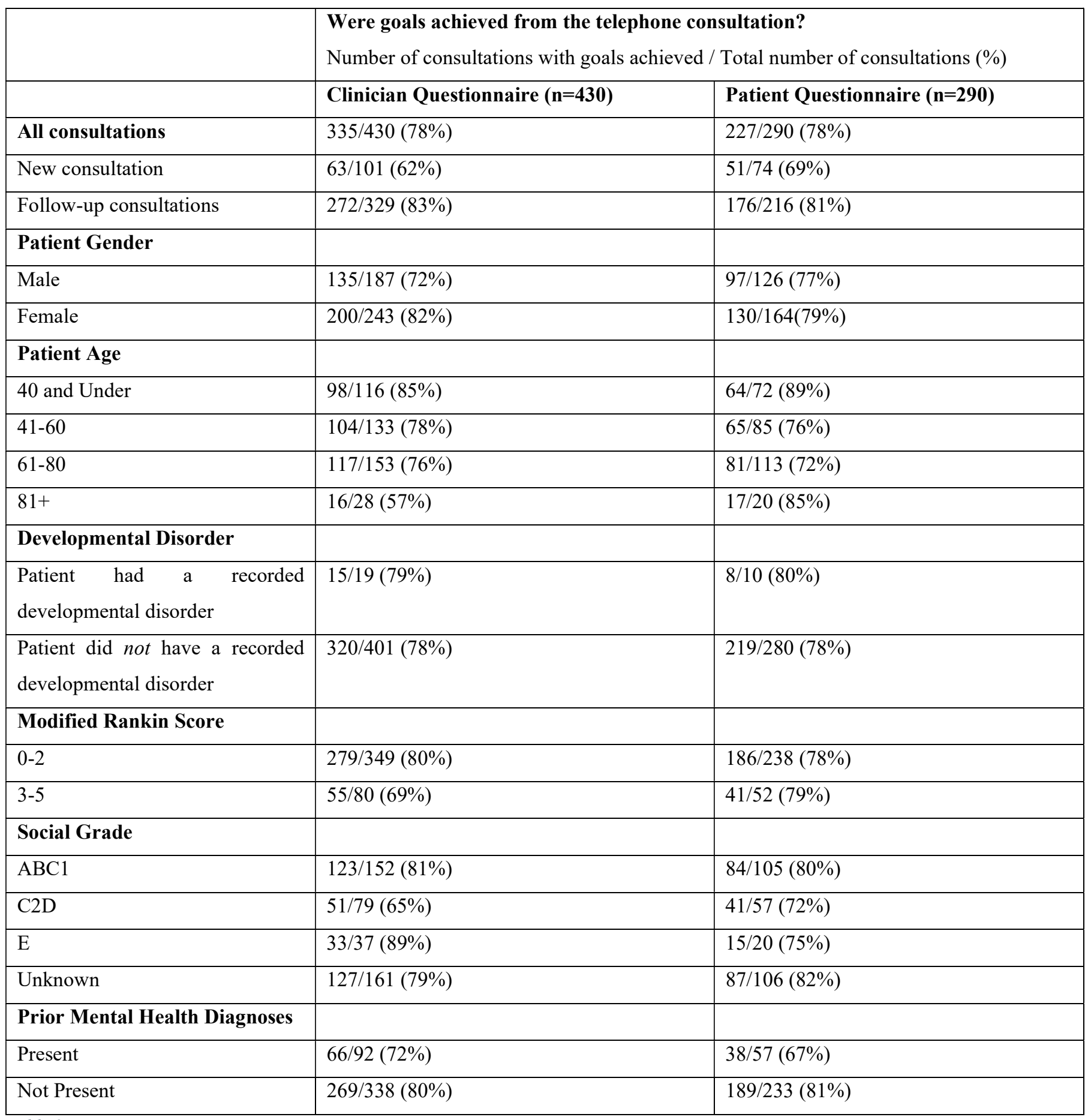
Table 2

The rate of clinician goal achievement also varied by presenting complaint (for new consultations) and for principal diagnosis (for follow-up consultations), Table 3. Clinicians achieved their goals almost universally with 
medRxiv preprint doi: https://doi.org/10.1101/2021.09.26.21264141; this version posted September 27, 2021. The copyright holder for this preprint (which was not certified by peer review) is the author/funder, who has granted medRxiv a license to display the preprint in

It is made available under a CC-BY-NC-ND 4.0 International license .

new and follow-up consultations concerning seizures or epilepsy. When these patients are excluded, clinicians achieved their goals in $48 \%$ of new consultations and $79 \%$ of follow-up consultations.

The only other group of new consultations where clinicians achieved their goals more often than not addressed sensory, motor or combined sensorimotor disturbance though the number of respondents is low ( $\mathrm{n}=25 \mathrm{in}$ total). In all other presenting complaints, clinicians achieved their goals less than half of the time in new consultations.

Table 3: Goal achievement divided by Table 3a: Presenting Complaint (for new consultations) and Table 3b: Primary Diagnosis (for follow-up consultations)

\begin{tabular}{|l|l|l|}
\hline & \multicolumn{2}{|l|}{$\begin{array}{l}\text { Were goals achieved from the telephone consultation? } \\
\text { Number of consultations with goals achieved / Total number of consultations (\%) }\end{array}$} \\
\hline $\begin{array}{l}\text { New consultations } \\
\text { (divided by presenting complaint) }\end{array}$ & Clinician Questionnaire & \multicolumn{2}{l|}{ Patient Questionnaire } \\
\hline Seizure or Epilepsy & $29 / 30(97 \%)$ & $18 / 24(75 \%)$ \\
\hline Headache & $5 / 13(39 \%)$ & $5 / 10(50 \%)$ \\
\hline Motor Disturbance & $5 / 9(56 \%)$ & $5 / 6(83 \%)$ \\
\hline Sensory and Motor Disturbance & $6 / 8(75 \%)$ & $4 / 6(67 \%)$ \\
\hline Sensory Disturbance & $5 / 8(63 \%)$ & $2 / 5(40 \%)$ \\
\hline Cognitive Problems & $2 / 5(40 \%)$ & $4 / 4(100 \%)$ \\
\hline Dizziness & $2 / 5(40 \%)$ & $3 / 4(75 \%)$ \\
\hline Visual Disturbance & $2 / 4(50 \%)$ & $3 / 3(100 \%)$ \\
\hline Speech Disturbance & $2 / 4(50 \%)$ & $1 / 3(33 \%)$ \\
\hline Tremor & $1 / 4(25 \%)$ & $1 / 3(33 \%)$ \\
\hline Collapse & $1 / 3(33 \%)$ & $3 / 3(100 \%)$ \\
\hline Other Presenting Complaint & $3 / 7(42 \%)$ & $2 / 3(67 \%)$ \\
\hline
\end{tabular}

Table 3A. *Other presenting complaint: 2 cases of hearing loss; single cases of: fatigue, family history of neurological disorder, functional neurological disorder, motor neurone disease second opinion

\begin{tabular}{|l|l|l|}
\hline & \multicolumn{2}{|l|}{$\begin{array}{l}\text { Were goals achieved from the telephone consultation? } \\
\text { Number of consultations with goals achieved / Total number of consultations (\%) }\end{array}$} \\
\hline $\begin{array}{l}\text { Follow-up consultations } \\
\text { (divided by primary diagnosis) }\end{array}$ & Clinician Questionnaire & Patient Questionnaire \\
\hline Parkinson's disease & $70 / 94(74 \%)$ & $50 / 65(77 \%)$ \\
\hline Epilepsy & $85 / 92(92 \%)$ & $53 / 57(93 \%)$ \\
\hline Huntington's Disease & $42 / 50(84 \%)$ & $16 / 22(73 \%)$ \\
\hline Multiple Sclerosis & $17 / 19(89 \%)$ & $16 / 16(100 \%)$ \\
\hline Primary Headache Disorders** & $17 / 18(94 \%)$ & $10 / 14(71 \%)$ \\
\hline Peripheral Neuropathy & $6 / 9(67 \%)$ & $7 / 8(88 \%)$ \\
\hline Mitochondrial Disorder & $4 / 6(67 \%)$ & $4 / 4(100 \%)$ \\
\hline
\end{tabular}


medRxiv preprint doi: https://doi.org/10.1101/2021.09.26.21264141; this version posted September $27,2021$. The copyright holder for this preprint (which was not certified by peer review) is the author/funder, who has granted medRxiv a license to display the preprint in It is made available under a CC-BY-NC-ND 4.0 International license .

\begin{tabular}{|l|l|l|}
\hline Idiopathic Intracranial Hypertension & $4 / 4(100 \%)$ & $2 / 3(67 \%)$ \\
\hline Autoimmune Encephalitis & $2 / 3(67 \%)$ & No Patient Responses \\
\hline Functional Neurological Disorder & $3 / 3(100 \%)$ & $1 / 2(50 \%)$ \\
\hline Myasthenia Gravis & $2 / 3(67 \%)$ & $1 / 3(33 \%)$ \\
\hline Myelopathy & $3 / 3(100 \%)$ & $1 / 3(33 \%)$ \\
\hline Neuromyelitis Optica & $2 / 2(100 \%)$ & $2 / 2(100 \%)$ \\
\hline Dementias & $2 / 2(100 \%)$ & No Patient Responses \\
\hline Other Primary Diagnosis*** & $10 / 17(59 \%)$ & $15 / 17(88 \%)$ \\
\hline None & $3 / 4(75 \%)$ & $3 / 3(100 \%)$ \\
\hline
\end{tabular}

Table 3B: **Primary Headache Disorders: migraine, cluster headache, tension headache and unspecified primary headache. ***Other Primary Diagnosis: single cases of Autosomal Dominant Leukodystrophy, Cerebellar Ataxia, CLIPPERS (Chronic Lymphocytic Inflammation with Pontine Perivascular Enhancement Responsive to Steroids), Cerebrospinal Fluid Leak, Dystonia (cause unclear), Hereditary Spastic Paraparesis, Lambert-Eaton Myasthenic Syndrome, Miller-Fisher syndrome, Multifactorial Dizziness, Neuroferritinopathy, Neurosarcoid, Orthostatic Tremor, Restless Leg Syndrome, Venous Sinus Thrombosis, Statin-induced Myositis, Stiff Person Syndrome, Ulnar Nerve Neuropathy

Amongst follow-up patients, clinicians achieved their aims more often than not across all primary diagnoses (Table 3); only consultations addressing peripheral neuropathy, mitochondrial disorder, autoimmune encephalitis and myasthenia gravis had achievement rates below 80\% (acknowledging small numbers in each). When clinicians did not achieve their aims, the telephone medium was usually the cause $(93 / 95,98 \%)$ principally reflecting the inability to examine the patient $(66 / 93,71 \%)$. This was particularly cited in appointments with patients new to the service (29/38 unsuccessful new consultations, 76\%). Less frequently cited reasons included in-clinic investigations $(\mathrm{n}=12$, of which 5 were in the transient ischaemic attack (TIA) clinic), patient deafness $(n=4)$, the need for a collateral history $(n=4)$ or cognitive assessment $(n=4)$. In 10/93 $(11 \%)$ multiple reasons were cited. In 40/93 (43\%) of consultations where clinicians did not achieve their aims due to the telephone, the clinicians deemed that a video consultation would have done so. Only 10/93 patients were felt to require urgent face-to-face clinical assessment and were re-booked in for a face-to-face appointment within one month of the telephone appointment ( 5 new patients, 5 follow-up patients).

Clinicians generally did not feel that the telephone consultation impaired the doctor-patient relationship (impaired in 55/430 consultations, $13 \%)$ though this figure was greater in new $(30 / 101,30 \%)$ compared to follow-up $(25 / 329,8 \%)$ consultations.

Finally, clinicians were asked about the duration of each telephone consultation compared to what they estimate they would have spent on the same face-to-face consultation. In both new and follow-up consultations, clinicians estimated that the telephone consultation required less time (41/101 (41\%) and 168/329 (51\%) respectively) or the same time (53/101 (53\%) and 145/329 (44\%) respectively) with only 5\% of consultations in each category taking longer by telephone. The median time difference for telephone consultations (compared to face-to-face consultations) was 0 mins for both new and follow up consultations (mean 2 minutes shorter and 3 minutes shorter respectively). Within new consultations, patients presenting with dizziness, motor or sensory disturbance or visual disturbance took shorter median consultation time than estimated face-to-face (all less than 5 minutes shorter) while no median difference was seen in any other presenting complaint (Fig. 1a). Follow-up consultations 
medRxiv preprint doi: https://doi.org/10.1101/2021.09.26.21264141; this version posted September $27,2021$. The copyright holder for this preprint (which was not certified by peer review) is the author/funder, who has granted medRxiv a license to display the preprint in It is made available under a CC-BY-NC-ND 4.0 International license .

addressing epilepsy, idiopathic intracranial hypertension and mitochondrial disorders took 5-10 minutes less time than estimated face-to-face consultations, while no median difference was seen in other primary diagnoses (Fig. 1b).

Fig. 1: Time difference for telephone consultation, compared to estimated face-to-face consultation, by Presenting Complaint (for new consultations, Fig. 1a) and by Primary Diagnosis (for follow-up consultations, Fig. 1b)

Fig. 1a

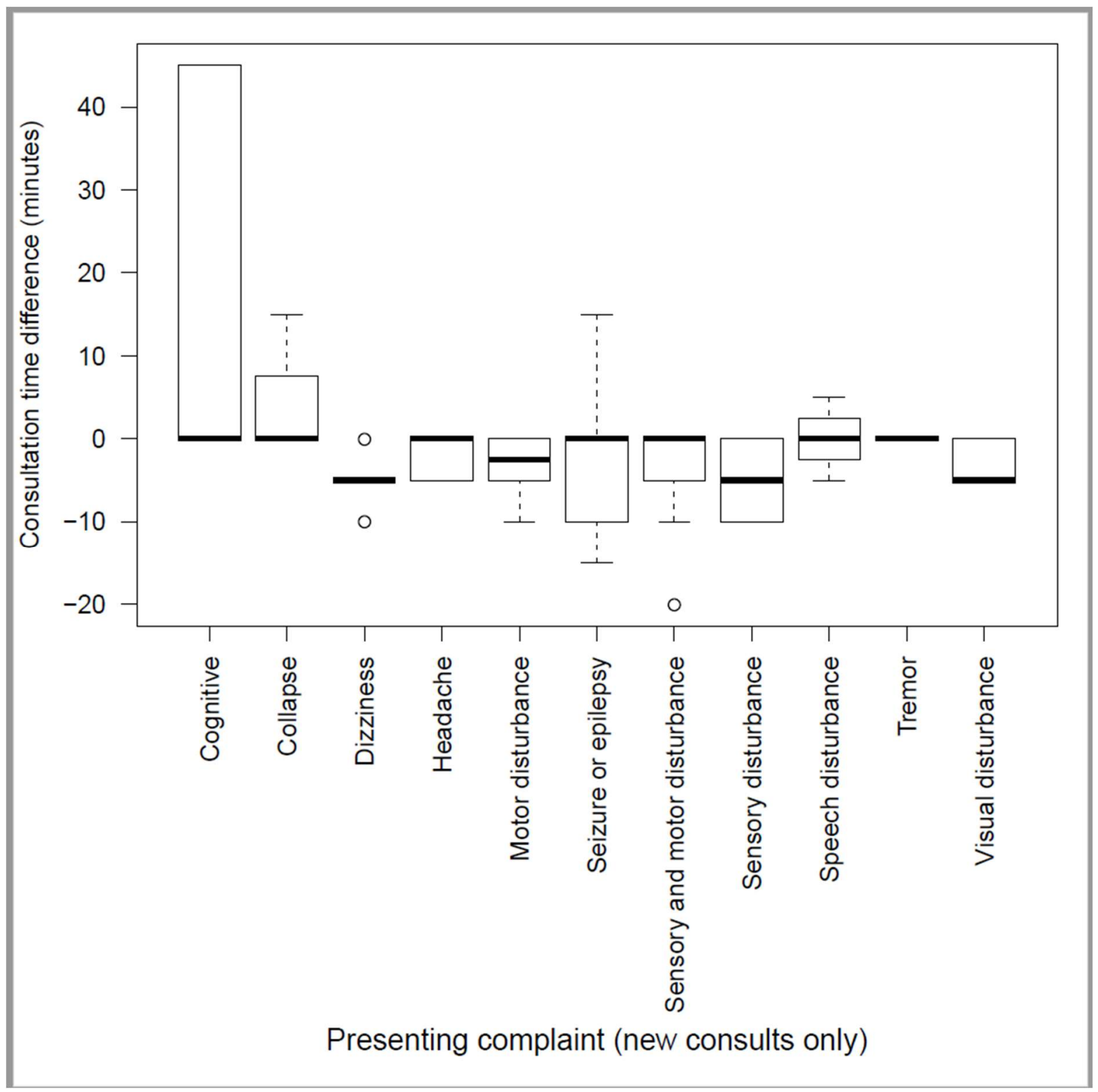


medRxiv preprint doi: https://doi.org/10.1101/2021.09.26.21264141; this version posted September $27,2021$. The copyright holder for this preprint (which was not certified by peer review) is the author/funder, who has granted medRxiv a license to display the preprint in It is made available under a CC-BY-NC-ND 4.0 International license .

Fig. 1 b

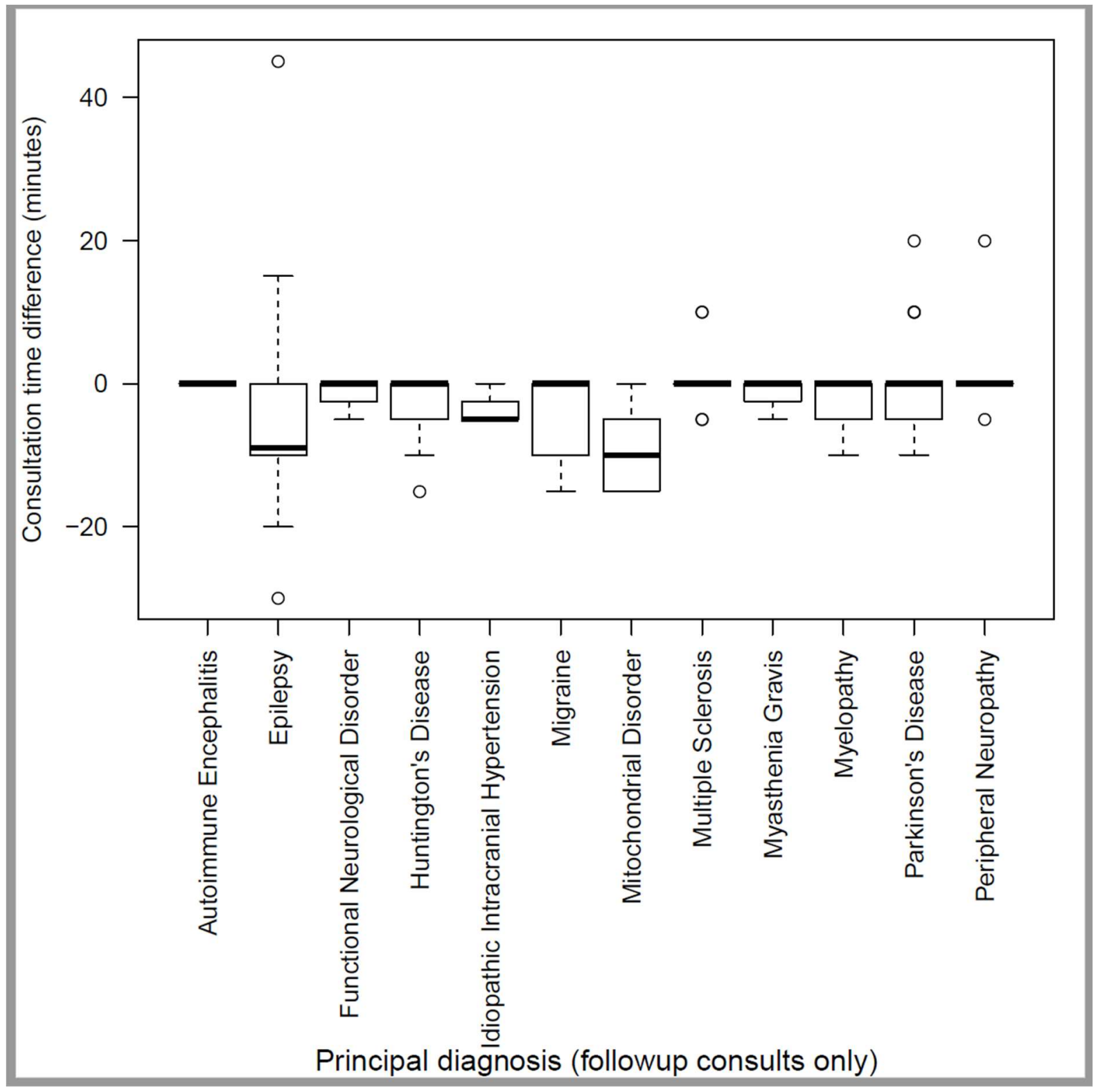


medRxiv preprint doi: https://doi.org/10.1101/2021.09.26.21264141; this version posted September $27,2021$. The copyright holder for this preprint (which was not certified by peer review) is the author/funder, who has granted medRxiv a license to display the preprint in

It is made available under a CC-BY-NC-ND 4.0 International license .

\section{Patient Questionnaires}

Patients were able to achieve their goals in 227/290 (78\%) of telephone consultations. Patient goals were achieved more often than not across all demographic subgroups (Table 2). Younger patients achieved their goals more frequently than older patients (though $73 \%$ of consultations with the over 60 s were still successful). Similar to clinicians' perception, patients were more likely to achieve their goals in follow-up (81\%) consultations as opposed to new (69\%) consultations. Of the patients that did not achieve their goals, 39/49 (80\%) attributed this at least partially to the telephone appointment.

Multiple reasons were cited for not achieving the consultation aims, and in over a third of such cases $(24 / 63)$ multiple reasons were cited. Overall, half $(33 / 63,52 \%)$ raised issues communicating over the phone, and just under a third $(20 / 63,32 \%)$ wanted a physical examination as part of the consultation. Seven patients $(11 \%)$ reported not feeling sufficiently in control of the consultation over the telephone.

Fifty-three patients (20\%) felt the telephone hampered the doctor-patient relationship, with minimal difference seen between follow-up $(34 / 197,17 \%)$ compared to new consultations $(19 / 71,21 \%)$.

Patients were also asked about the practicality and ease of attending a telephone appointment compared to a faceto-face appointment. The majority of respondents $(203 / 285,69 \%)$ found the telephone consultation more convenient or practical than a face-to-face consultation. Of note, 101/285 (35\%) patients were employed at the time of the consultation, 97 of which needed to take time off work for their consultations (mean 5.4 (standard deviation (SD) 5.0) working hours lost). Furthermore, most patients (201/285, 70\%) would be accompanied to face-to-face consultations by a family member or friend, of which half $(102 / 201,50 \%)$ would also take time off work to attend. Patients also generally reported having to spend an average of two and a half hours (mean 157 mins, SD 86 mins) attending an appointment, including return travel time.

Finally, patients were asked about their preferences for future consultations. Of 211 respondents, 62 (29\%) wanted exclusively face-to-face consultations, 56 (27\%) wanted only telephone or video consultations or a mixture of the two, while 93 (44\%) wanted a mixture of face-to-face consultations with either telephone or video consultations (Table 4). These preferences varied by age, with older patients generally preferring future consultations to all be face-to-face, and younger patients preferring at least some telephone and video appointments. Despite the high goal achievement by patients with epilepsy (93\%) and multiple sclerosis (100\%), Table 3, future consultations wanted at least some face-to-face consultations in 42/62 and 7/12 respectively (Table 4).

Table 4: Patient preference for future consultations, with comparison by mean age of patient and percentage of patients in new consultations

\begin{tabular}{|l|l|l|l|}
\hline $\begin{array}{l}\text { Patient preference for future } \\
\text { consultations: }\end{array}$ & Number (\%) & $\begin{array}{l}\text { Mean age (standard } \\
\text { deviation), years }\end{array}$ & $\begin{array}{l}\text { Number (\%) undergoing new } \\
\text { consultation when surveyed }\end{array}$ \\
\hline All face-to-face & $62(29 \%)$ & $60.4( \pm 17.5)$ & $16(26 \%)$ \\
\hline All by telephone & $22(10 \%)$ & $49.0( \pm 15.5)$ & $5(8 \%)$ \\
\hline All by video & $7(3 \%)$ & $56.3( \pm 18.1)$ & $2(3 \%)$ \\
\hline
\end{tabular}


medRxiv preprint doi: https://doi.org/10.1101/2021.09.26.21264141; this version posted September $27,2021$. The copyright holder for this preprint (which was not certified by peer review) is the author/funder, who has granted medRxiv a license to display the preprint in

It is made available under a CC-BY-NC-ND 4.0 International license.

\begin{tabular}{|l|l|l|l|}
\hline Mix of face-to-face and telephone & $53(25 \%)$ & $49.4( \pm 19.6)$ & $14(23 \%)$ \\
\hline Mix of face-to-face and video & $40(19 \%)$ & $52.5( \pm 19.7)$ & $17(28 \%)$ \\
\hline Mix of telephone and video & $27(13 \%)$ & $45.0( \pm 17.9)$ & $7(12 \%)$ \\
\hline
\end{tabular}

Table 5: Patient preferences for future consultations, by Diagnosis (Only if $>10$ respondents to question)

\begin{tabular}{|l|l|l|l|l|l|l|l|}
\hline $\begin{array}{l}\text { Patient } \\
\text { preference } \\
\text { for future } \\
\text { consultations } \\
\text { by Diagnosis: }\end{array}$ & $\begin{array}{l}\text { All Face- } \\
\text { to-Face }\end{array}$ & $\begin{array}{l}\text { All } \\
\text { Telephone }\end{array}$ & All Video & $\begin{array}{l}\text { Mix of } \\
\text { Face-to- } \\
\text { Face and } \\
\text { Telephone }\end{array}$ & $\begin{array}{l}\text { Mix of } \\
\text { Face-to- } \\
\text { Face and } \\
\text { Video }\end{array}$ & $\begin{array}{l}\text { Mix of } \\
\text { Telephone } \\
\text { and Video }\end{array}$ & Respondents \\
\hline Epilepsy & $15(24 \%)$ & $7(11 \%)$ & $1(2 \%)$ & $16(26 \%)$ & $11(18 \%)$ & $12(19 \%)$ & 62 \\
\hline $\begin{array}{l}\text { Parkinson's } \\
\text { Disease }\end{array}$ & $12(30 \%)$ & $2(5 \%)$ & $2(5 \%)$ & $11(28 \%)$ & $11(28 \%)$ & $2(5 \%)$ & 40 \\
\hline Migraine & $3(23 \%)$ & $0(0 \%)$ & $1(8 \%)$ & $4(31 \%)$ & $3(23 \%)$ & $2(15 \%)$ & 13 \\
\hline $\begin{array}{l}\text { Huntington's } \\
\text { Disease }\end{array}$ & $6(50 \%)$ & $3(25 \%)$ & $0(0 \%)$ & $1(8 \%)$ & $1(8 \%)$ & $1(8 \%)$ & 12 \\
\hline $\begin{array}{l}\text { Multiple } \\
\text { Sclerosis }\end{array}$ & $2(17 \%)$ & $4(33 \%)$ & $0(0 \%)$ & $4(33 \%)$ & $1(8 \%)$ & $1(8 \%)$ & 12 \\
\hline
\end{tabular}

\section{Discussion}

Converging evidence from patients and clinicians found that in particular settings - any seizure or epilepsy consultation; follow-up consultations for most diseases; and consultations with younger patients - telephone consultations may be advantageous for future care delivery, probably in combination with face-to-face consultations. Across all demographics, clinicians and patients achieved their goals from telephone consultations more often than not: in follow-up consultations, goal achievement exceeded $80 \%$ in patients with primary diagnoses of epilepsy, Huntington's disease, multiple sclerosis and migraine; $50-83 \%$ of these subgroups wanted future consultations to include telephone or video consultations; and the consultation itself took the same or less time than face-to-face consultations.

With the exception of seizures or epilepsy, new consultations delivered by telephone were not associated with high goal achievement from clinicians $(34 / 71,48 \%)$ or patients $(33 / 56,59 \%)$. For clinicians, this predominantly reflected the inability to examine the patient and to a lesser extent, in-clinic investigations. A video consultation was predicted to have enabled clinician goal achievement in 13 instances, bringing the total clinician success rate to $76 / 101$ for all new consultations. However, some factors driving unsuccessful telephone consultations (particularly increasing age and lower socioeconomic status) will likely impair video consultations [11, 12]. Future work comparing face-to-face, telephone and video consultations across all demographics and disease types is now required. 
medRxiv preprint doi: https://doi.org/10.1101/2021.09.26.21264141; this version posted September $27,2021$. The copyright holder for this preprint (which was not certified by peer review) is the author/funder, who has granted medRxiv a license to display the preprint in It is made available under a CC-BY-NC-ND 4.0 International license.

The telephone was deemed to have impacted on the clinician-patient relationship in less than $20 \%$ of consultations. More than one third of patients questioned were employed prior to the pandemic (necessitating missing half a day of work to attend face-to-face appointments) while more than two thirds would be accompanied by a family member, friend or carer, of which half would also need to take time off from work to attend. The reported convenience of a telephone appointment for patients may stem from this, from the driving restrictions resulting from certain neurological diagnoses (particularly seizures and epilepsy) and from the lower perceived value of facets requiring face-to-face consultation (such as clinical examination) in some follow-up scenarios, particularly headache or epilepsy.

To the best of our knowledge this is the first simultaneous assessment of patient and clinician perceptions of telephone consultations, incorporating a broad and unselected range of adult neurological presentations, solely using the telephone (as opposed to video) medium. With the exception of age and disease, we found no consistent relationship between demographics and consultation success. The absence of a relationship between socioeconomic status and goal achievement may reflect our crude method of quantifying socioeconomic status, the relative affluence of the surrounding areas or a true lack of an effect. Our overall findings on patient and clinician satisfaction are broadly in line with other studies and adds to the body of evidence produced both prior to and as a result of the pandemic [13-19].

Our findings are also in line with the approach outlined by NHS England/National Institute of Clinical Excellence (NICE) suggesting that remote consultations are more appropriate for consultations of chronic, stable patients, where a physical examination may not be required.[8] It also provides the beginnings of an evidence base for which hospitals can start adapting to digital health clinics as part of the pre-pandemic NHS Long Term Plan to move up to a third of visits non face-to-face.[20]

A number of limitations are worth addressing. Foremostly, many presentations or diagnoses are underrepresented, reflecting the finite period when unselected referrals were converted to telephone clinics (following which a more judicious approach based on clinician experience was adopted). Additionally, the peripheral nerve service did not undertake telephone consultations due to the importance of the clinical examination to their clinical assessments; the small number of neuropathies included here were those from general clinics so are not generalisable. The majority of patient questionnaires were collected by telephone rather than written, but we found no meaningful difference between the rates of patient-reported goal achievement or patient's future consultation medium preference between the two approaches suggesting this methodological issue did not introduce bias. To improve uptake and avoid unnecessary burden we relied on self-reported consultation duration from clinicians which may not be accurate. Some demographic factors (such as the social grade or presence of a mental health diagnosis) relied on the information to be present in clinic and referral letters, so may also be incomplete. The lack of trainee clinics (due to clinical redeployments) and small number of nurse specialist consultations (from epilepsy and headache) precluded exploring whether goal achievement varied due to clinician type. All surveys are inherently prone to respondent bias with those responding potentially more likely to have had particularly negative or positive experiences: the high response rate should have minimised this. Finally, this was a single centre survey, and should be repeated in other centres, comparing face-to-face, video and telephone consultations to seek whether our findings are generalisable; and, if so, whether an algorithmic triage process can be employed 
medRxiv preprint doi: https://doi.org/10.1101/2021.09.26.21264141; this version posted September 27, 2021. The copyright holder for this preprint (which was not certified by peer review) is the author/funder, who has granted medRxiv a license to display the preprint in It is made available under a CC-BY-NC-ND 4.0 International license .

by non-clinical staff at the time of appointment booking to determine the appropriate consultation modality. As highlighted by other studies conducted during the pandemic, these clinics represent a snapshot of a single neurological consultation and may not be indicative of successful longer term outcomes and care.

In conclusion, subgroups of neurology outpatient consultations appear effective, convenient and popular when delivered by telemedicine. A mixture of such remote methods with face-to-face consultations appears the most popular approach with patients. 
medRxiv preprint doi: https://doi.org/10.1101/2021.09.26.21264141; this version posted September 27, 2021. The copyright holder for this preprint (which was not certified by peer review) is the author/funder, who has granted medRxiv a license to display the preprint in It is made available under a CC-BY-NC-ND 4.0 International license .

\section{Appendix A: Clinician Questionnaire}

\section{After each telephone consultation (not advice and guidance):}

1. Did you achieve what you wanted from the appointment?

$\square$ Yes $\square$ No

If No, please list what was not possible:

If No, was this because of the telephone consultation?

$\square$ Yes $\square$ No

If No, would a video consultation have overcome these limitations?

$\square$ Yes $\square$ No

2. Did the telephone consultation hamper your relationship with the patient?

$\square$ Yes $\square$ No

3. Did the consultation take less, similar or more time compared to a face-to-face consultation?

Less $\square$ Same $\square$ More

Please quantify this time difference (e.g. -5 for 5 minutes less): $\quad \ldots \ldots \ldots \ldots . . .$. mins

\section{Appendix B: Patient Questionnaire}

Please review the questions below and tick one of the following options per question:

Q1. Did you achieve what you wanted to from the consultation?

$\square$ Yes $\square$ No

A. If No, please outline what you felt unable to achieve:

B. If you did not achieve what you wanted to from the consultation, was this because of the consultation being delivered by telephone (instead of face-to-face)?

Q2. Compared to a face-to-face consultation, did you feel that the telephone consultation impaired the appointment?

$\square$ Yes $\square$ No

A. If Yes, please outline how the telephone consultation impaired or hampered the consultation:

B. Specifically, did you feel it hampered the doctor-patient relationship?

$\square$ Yes $\quad \square$ No 
medRxiv preprint doi: https://doi.org/10.1101/2021.09.26.21264141; this version posted September 27, 2021. The copyright holder for this preprint (which was not certified by peer review) is the author/funder, who has granted medRxiv a license to display the preprint in

It is made available under a CC-BY-NC-ND 4.0 International license .

Q3. For a face-to-face consultation, please give the total time you would typically spend attending a neurology appointment (including for example the time spent travelling to the appointment, parking, time in the clinic itself, and time travelling home)

hours and .minutes

Q4. Prior to the Covid-19 pandemic did you have a job?

Yes

No

A. If Yes, please tell us how much time you would take off from work to attend the appointment (or whether you took the whole day off work):

Whole day or hours

Q5. For a face-to-face consultation, are you usually accompanied by a relative, friend or carer?

Yes

No

A. If Yes, what is the total time this relative/friend/carer would typically spend attending a neurology appointment with you (including for example the time spent travelling to your home, travelling from your home to the appointment, parking, in the clinic itself, travelling back to your home and travelling back to their home)?

.hours and minutes.

B. Prior to the Covid-19 pandemic did this relative, friend or carer have a job?

Yes

No

Q6. Overall, do you feel that telephone consultations are likely to be more practical / convenient for you compared to face-to-face consultations?

Yes

No

Q7. We have now been permitted to use video consultations, where you can hear and see the doctor from your mobile phone or computer; and they can hear and see you). Overall, would you prefer telephone, face-to-face or video consultations or a mixture (if telephone or video consultations were used the clinician or patientcould always request a face-to-face consultation if required)? We are seeking your opinion only; your individual answer will not influence whether your next appointment is face-to-face, video or telephone)

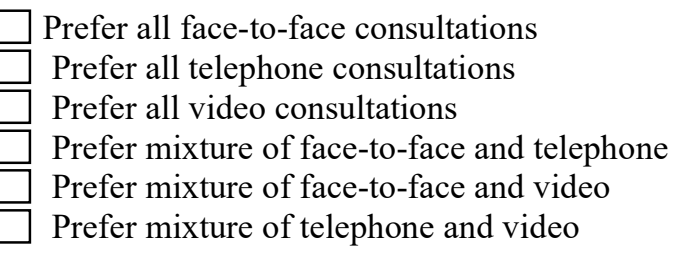

Q8. Finally, compared to a face-to-face consultation, please tell us anything else you found positive about having a telephone consultation; and anything else you found negative about have a telephone consultation 
medRxiv preprint doi: https://doi.org/10.1101/2021.09.26.21264141; this version posted September $27,2021$. The copyright holder for this preprint (which was not certified by peer review) is the author/funder, who has granted medRxiv a license to display the preprint in It is made available under a CC-BY-NC-ND 4.0 International license .

\section{Supplementary Data}

Table S1: Questionnaire Respondent vs Non-Respondent Demographics

\begin{tabular}{|l|l|l|l|}
\hline Questionnaire & Respondents & Non-Respondents & All \\
\hline Total & $298(69 \%)$ & 132 & 430 \\
\hline Mean Age (SD, Range) & $55.9(18.8,17-93)$ & $51.0(18.5,17-90)$ & $54.3(18.8,17-93)$ \\
\hline Gender M/F (\% Male) & $130 / 168(44 \%)$ & $57 / 75(43 \%)$ & $187 / 243(43 \%)$ \\
\hline New/Follow-up (\%New) & $75 / 223(25 \%)$ & $26 / 106(20 \%)$ & $101 / 329(23 \%)$ \\
\hline
\end{tabular}


medRxiv preprint doi: https://doi.org/10.1101/2021.09.26.21264141; this version posted September 27,2021 . The copyright holder for this preprint (which was not certified by peer review) is the author/funder, who has granted medRxiv a license to display the preprint in

It is made available under a CC-BY-NC-ND 4.0 International license .

\section{References}

1. Davis LE, Harnar J, Lachey-Barbee LA, Pirio Richardson S, Fraser A, King MK (2019) Using Teleneurology to Deliver Chronic Neurologic Care to Rural Veterans: Analysis of the First 1,100 Patient Visits. Telemed e-Health 25:274-278 . https://doi.org/10.1089/tmj.2018.0067

2. Duncan C, Macleod AD (2020) Video consultations in ordinary and extraordinary times. Pract Neurol 20:396-403 . https://doi.org/10.1136/practneurol-2020-002579

3. Rubin MN, Demaerschalk BM (2014) The use of telemedicine in the management of acute stroke. Neurosurg Focus 36:1-5 . https://doi.org/10.3171/2013.11.FOCUS13428

4. Kepplinger J, Barlinn K, Deckert S, Scheibe M, Bodechtel U, Schmitt J (2016) Safety and efficacy of thrombolysis in telestroke. Neurology 87:1344-1351 . https://doi.org/10.1212/WNL.0000000000003148

5. Rasmusson KA, Hartshorn JC (2005) A comparison of epilepsy patients in a traditional ambulatory clinic and a telemedicine clinic. Epilepsia 46:767-770 . https://doi.org/10.1111/j.1528-

1167.2005.44804.x

6. Fesler JR, Stanton S, Merner K, Ross L, McGinley MP, Bena J, Rasmussen P, Najm I, Punia V (2020) Bridging the gap in epilepsy care: A single-center experience of 3700 outpatient tele-epilepsy visits. Epilepsia 61:e95-e100 . https://doi.org/10.1111/epi.16619

7. Hatcher-Martin JM, Adams JL, Anderson ER, Bove R, Burrus TM, Chehrenama M, Dolan O'Brien M, Eliashiv DS, Erten-Lyons D, Giesser BS, Moo LR, Narayanaswami P, Rossi MA, Soni M, Tariq N, Tsao JW, Vargas BB, Vota SA, Wessels SR, Planalp H, Govindarajan R (2020) Telemedicine in neurology: Telemedicine Work Group of the American Academy of Neurology update. Neurology 94:30-38 . https://doi.org/10.1212/WNL.0000000000008708

8. National Institutes for Health and Clinical Excellence (2020) Specialty guides for patient management during the coronavirus pandemic Clinical guide for the management of remote consultations and remote working in secondary care during the coronavirus pandemic

9. UK TIA Study Group (1988) United Kingdom transient ischaemic attack (UK-TIA) aspirin trial: Interim results. Br Med J (Clin Res Ed) 296:316-320 . https://doi.org/10.1136/bmj.296.6618.316

10. Park TH, Lee JK, Park MS, Park SS, Hong KS, Ryu WS, Kim DE, Park MS, Choi KH, Kim JT, Kang J, Kim BJ, Han MK, Lee J, Cha JK, Kim DH, Kim JG, Lee SJ, Cho YJ, Kwon JH, Shin DI, Yeo MJ, Sohn S Il, Hong JH, Lee JS, Choi JC, Kim WJ, Lee BC, Yu KH, Oh MS, Park JM, Kang K, Lee KB, Lee J, Gorelick PB, Bae HJ (2020) Neurologic deterioration in patients with acute ischemic stroke or transient ischemic attack

11. Eberly LA, Kallan MJ, Julien HM, Haynes N, Khatana SAM, Nathan AS, Snider C, Chokshi NP, Eneanya ND, Takvorian SU, Anastos-Wallen R, Chaiyachati K, Ambrose M, O’Quinn R, Seigerman M, Goldberg LR, Leri D, Choi K, Gitelman Y, Kolansky DM, Cappola TP, Ferrari VA, Hanson CW, Deleener ME, Adusumalli S (2020) Patient Characteristics Associated With Telemedicine Access for Primary and Specialty Ambulatory Care During the COVID-19 Pandemic. JAMA Netw Open 3:e2031640 . https://doi.org/10.1001/jamanetworkopen.2020.31640

12. Gursky JM, Boro A, Escalante S, Ferastraoaru V, Hanumanthu R, Haut S, Jehle R, Molinero I, Rick L, Rosengard J, Saifeddine M, Sugrue W, Moshé SL, Ballaban-Gil K (2020) A Bronx Tale: Disparities in Access to Neurologic Telemedicine During the COVID-19 Pandemic. Neurol Clin Pract 
medRxiv preprint doi: https://doi.org/10.1101/2021.09.26.21264141; this version posted September $27,2021$. The copyright holder for this preprint (which was not certified by peer review) is the author/funder, who has granted medRxiv a license to display the preprint in

It is made available under a CC-BY-NC-ND 4.0 International license.

10.1212/CPJ.0000000000001028 . https://doi.org/10.1212/cpj.0000000000001028

13. Esper CD, Scorr L, Papazian S, Bartholomew D, Esper GJ, Factor SA (2021) Telemedicine in an Academic Movement Disorders Center during COVID-19. J Mov Disord 1-7 .

https://doi.org/10.14802/jmd.20099

14. Rosellini I, Vianello M, Ghazaryan A, Silvia VG, Palmieri A, Giopato F, Vitaliani R, Fuccaro M, Terrin A, Rigoni MT, Pietrobon F, Bonifati DM (2021) Virtual visits for chronic neurologic disorders during COVID-19 pandemic. Neurol Sci 10-13 . https://doi.org/10.1007/s10072-021-05212-3

15. Corea F, Ciotti S, Cometa A, De Carlo C, Martini G, Baratta S, Zampolini M (2021) Telemedicine during the coronavirus disease (Covid-19) pandemic: A multiple sclerosis (ms) outpatients service perspective. Neurol Int 13:1-7 . https://doi.org/10.3390/neurolint13010003

16. Vollmuth C, Miljukov O, Abu-Mugheisib M, Angermaier A, Barlinn J, Busetto L, Grau AJ, Guenther A, Gumbinger C, Hubert N, Hüttemann K, Klingner C, Naumann M, Palm F, Remi J, Rücker V, Schessl J, Schlachetzki F, Schuppner R, Schwab S, Schwartz A, Trommer A, Urbanek C, Volbers B, Weber J, Wojciechowski C, Worthmann H, Zickler P, Heuschmann PU, Haeusler KG, Hubert GJ (2021) Impact of the coronavirus disease 2019 pandemic on stroke teleconsultations in Germany in the first half of 2020. Eur J Neurol 1-12 . https://doi.org/10.1111/ene.14787

17. Kristoffersen ES, Sandset EC, Winsvold BS, Faiz KW, Storstein AM (2021) Experiences of telemedicine in neurological out-patient clinics during the COVID-19 pandemic. Ann Clin Transl Neurol 8:440-447 . https://doi.org/10.1002/acn3.51293

18. Banks J, Corrigan D, Grogan R, El-Naggar H, White M, Doran E, Synnott C, Fitzsimons M, Delanty N, Doherty CP (2021) LoVE in a time of CoVID: Clinician and patient experience using telemedicine for chronic epilepsy management. Epilepsy Behav 115:107675 .

https://doi.org/10.1016/j.yebeh.2020.107675

19. Rametta SC, Fridinger SE, Gonzalez AK, Xian J, Galer PD, Kaufman M, Prelack MS, Sharif U, Fitzgerald MP, Melamed SE, Malcolm MP, Kessler SK, Stephenson DJ, Banwell BL, Abend NS, Helbig I (2020) Analyzing 2,589 child neurology telehealth encounters necessitated by the COVID-19 pandemic. Neurology 95:e1257-e1266 . https://doi.org/10.1212/WNL.0000000000010010

20. NHS England (2019) The NHS Long Term Plan 
medRxiv preprint doi: https://doi.org/10.1101/2021.09.26.21264141; this version posted September $27,2021$. The copyright holder for this preprint (which was not certified by peer review) is the author/funder, who has granted medRxiv a license to display the preprint in It is made available under a CC-BY-NC-ND 4.0 International license .

\section{Acknowledgements}

\section{Author Information}

\section{Affiliations}

T Nakornchai BSc MRCP

Department of Clinical Neurosciences, University of Cambridge, Cambridge, United Kingdom

Department of Neurology, Addenbrooke's Hospital, Cambridge University Hospitals NHS Foundation Trust, Cambridge, United Kingdom

ORCID ID: 0000-0003-1573-9812

\section{E Conci BA MB BChir}

Department of Neurology, Addenbrooke's Hospital, Cambridge University Hospitals NHS Foundation Trust, Cambridge, United Kingdom

\section{A Hensiek PhD FRCP}

Department of Neurology, Addenbrooke's Hospital, Cambridge University Hospitals NHS Foundation Trust, Cambridge, United Kingdom

\section{J William L Brown PhD MRCP}

Department of Clinical Neurosciences, University of Cambridge, Cambridge, United Kingdom

NMR Research Unit, Queen Square Multiple Sclerosis Centre, University College London (UCL) Institute of Neurology, London, United Kingdom

Clinical Outcomes Research Unit (CORe), University of Melbourne, Melbourne, Australia

Department of Neurology, Addenbrooke's Hospital, Cambridge University Hospitals NHS Foundation Trust, Cambridge, United Kingdom

ORCID ID: 0000-0002-7737-5834

\section{Corresponding Author}

Correspondence to Dr T Nakornchai <tagore.nakornchai@nhs.net>

\section{Declarations}

Funding: The authors received no funding for this work.

Conflicts of interests: The authors have no disclosures.

Data and Code availability: The data that support the findings of this study and the code used to analyse the data are available from the corresponding author, upon reasonable request.

Ethics approval: This study was approved by the by the Cambridge University Hospitals clinical governance department. 
medRxiv preprint doi: https://doi.org/10.1101/2021.09.26.21264141; this version posted September 27, 2021. The copyright holder for this preprint (which was not certified by peer review) is the author/funder, who has granted medRxiv a license to display the preprint in It is made available under a CC-BY-NC-ND 4.0 International license.

Consent to participate: Informed consent was obtained from all individual participants included in the study.

Consent for publication: The Corresponding Author transfers to the BMJ the publication rights and he warrants that his contribution is original and that he has full power to make this grant.

Authors' contributions: JWLB and AH conceptualised the study, JWLB and TN designed the study, TN and EC performed the data collection, TN and JWLB performed the statistical analysis. TN drafted the original manuscript. All authors have reviewed and contributed to the final manuscript. 